\title{
An Investigation of Teacher Behaviors in Terms of Values Education According to Their Colleagues' Views*
}

\author{
Abdurrahman KILIÇ** \\ Özlem ALBAYRAKOĞLU ${ }^{* * * * *}$
}

\author{
Şeyma ŞAHİN ${ }^{* * *}$ \\ Zeynep ARSEVEN ${ }^{* * * * * *}$
}

Received: 13 February 2015

Accepted: 22 May 2015

\begin{abstract}
It is assumed that teaching and values education are associated in a way that none of them could be defined or considered separately. Since, teachers who have a very important place in the development of students' value system must present those desired values in their lives, especially in their behaviors. Teacher behaviors considered to be important and meaningful to understand current situation of values that both students and society have. The aim of this study is to investigate teacher behaviors according to their colleagues' beliefs in terms of values education. The method of the study is chosen to be qualitative and the study group consists of teachers from different school levels in Düzce, Turkey. Data were collected through a semi-structured interview form and were content analyzed. According to the results, it is found out that some behaviors of teachers damage values in all school levels.
\end{abstract}

Keywords: Values, values education, teacher behaviors.

\section{Extended Abstract}

"Actions speak louder than words."

The term 'values' refers to the principles and fundamental convictions which act as general guides to behaviour, the standards by which particular actions are judged to be good or desirable (Halstead \& Taylor, 2000:169). Values, which a society should have, are the most important criteria that make the socio-economic elements meaningful (Özensel, 2003). With values, an individual identifies what is important and tends to favor a particular situation to another. Therefore, values are principles and standards that guide individuals and help them shape their actions and attitudes in different situations. Values function as a guide for individuals and they block undesired behaviors and direct individuals through desired or right behaviors. Ideally, positive values and attitudes are revealed as well-adjusted behaviors (Aktay \& Ekşi, 2009; Bektaş \& Nalçac1, 2012; Gül, 2013; Okumuş, 2010; Özdaş, 2013).

*A part of this study was presented at YICER, September 01-03, 2014

${ }^{* *}$ Corresponding Author: Prof. Dr., Duzce University, Duzce, Turkey, abdurrahmankilic@ duzce.edu.tr

${ }^{* * *}$ PhD Student, Duzce University, Duzce, Turkey, seyymasahin@gmail.com

*****PhD Student, Abant Izzet Baysal University, Bolu, Turkey,ozlem_cap@yahoo.com

***** Research Assistant, Duzce University, Duzce, Turkey, zeyneparseven@ duzce.edu.tr

\section{Citation Information}

Kılıç, A., Şahin, Ş., Albayrakoğlu, Ö., \& Arseven, Z. (2016). Öğretmen görüşlerine göre öğretmen davranışlarının değerler eğitimi açısından incelenmesi. Kuramsal Eğitimbilim Dergisi [Journal of Theoretical Educational Science], 9(3), 441-460. 
Purpose and Significance: During the formation of values of an individual, there can be many factors that should be considered; family, school, social environment, and media (Akbaş, 2004; Yalar, 2010). Although these factors are intertwined with each other, the most effective ones are the social environment and school, especially during the ages of social and moral development of individuals. Schools are the places where an individual applies, internalizes, and strengthens the values, which s/he gained from his family (Keskin, 2008). Thus, schools are the most important step of value acquisition. Values education at schools is a hot topic in recent years. According to Keskin (2008), the most important side of teaching values is transmitting the social values to next generation and schools should perform this role. Nevertheless, the values education or character education in schools keeps up with a hidden curriculum. A hidden curriculum, which is a very powerful tool, is a part of the learning process in schools and often used in transmitting knowledge, values, and beliefs (Akbaş, 2004; Doğanay \& Sar1, 2004; Sar1, 2007). Students spend most of their time in their daily routines with teachers. This situation makes teachers the most effective group so values and qualifications they have or supposed to have become an effective way of transmitting values (Akbaş, 2004; Doğanay \& Sar1, 2004; Sar1, 2007). Therefore, personal qualities of teachers are important and also come before the professional qualifications. Children gain identity not only by their incentives, but also by establishing the role of their peers' and teachers' attitudes and values (Sünbül, 1996). Teachers should be aware of their responsibilities as value carriers and care about the ideal values. If teachers do not have the desired values, not only values formation will be interrupted but also students' existing values may be harmed and would be disappeared. In this study, it is aimed to understand behaviors of teachers that could damage values from the perspective of their colleagues. Our goal is to put a mirror to teachers and help them clarify their acts, behaviors, and attitudes.

Methods: The method was chosen to be qualitative and the study had a phenomenological design. Qualitative research contributes to the collection of data in a realistic and holistic way in its natural environment, tries to understand how people reveal the world, and make sense of their lives (Merriam, 2009; Yıldırım \& Şimşek, 2008). Study groups of the study were selected through maximum variation sampling, which is a purposeful sampling. In phenomenological research, data were collected from individuals or groups, who are at the center of research and willing to express the feelings and experiences they have about the phenomenon. The study group is composed of five primary, three secondary and four high school teachers, who were chosen from different subjects in different schools in Düzce. Data were collected through semi-structured interviews and interview questions were developed through the literature review. Some expert opinions were obtained, and necessary arrangements were done on the questions before they were used. Researchers asked questions in the form of one by one and depending on the flow of conversation some extra questions 
were also asked to make answers elaborate. Researchers analyzed the data using content analysis, encoded the data as negative teacher behaviors, and then identified common negative teacher behaviors. Determined negative teacher behaviors were grouped under same main categories and values that undermine these main categories were identified.

Results: The findings of the analysis are grouped under four headings according to three school levels and a comparison of all. According to the views of primary school teachers, negative behaviors that have been seen in their colleagues, which are found to be undermining the values, are grouped in five different sets of values: justice, respecttolerance-sincerity, responsibility, compassion-patience and sacrifice-solidarity. The findings according to secondary school teachers were grouped in nine different set of values: justice, respect-tolerance-sincerity, modesty, temperance, responsibility, compassion-patience, being a model, being hardworking-succeed, sacrifice and solidarity. Finally, the findings according to high school teachers were grouped in ten different sets of values: justice, respect-tolerance-friendliness, humility, truth, temperance, responsibility, compassion-patience, being a model, being hardworkingsuccessful, sacrifice and solidarity.

Discussion and Conclusions: In conclusion, behaviors that damage values are grouped under five in primary level, nine in secondary level and 10 behaviors in high school level. This situation reveals that as the education level increases, the numbers of values that get damaged are increased. In order to avoid such results, some suggestions were developed. 


\title{
Öğretmen Görüşlerine Göre Öğretmen Davranışlarının Değerler Eğitimi Açısından İncelenmesi*
}

\author{
Abdurrahman KILIÇ ${ }^{* *}$ \\ Özlem ALBAYRAKOĞLU ${ }^{* * * * *}$
}

\author{
Şeyma ŞAHİN*** \\ Zeynep ARSEVEN ${ }^{* * * * *}$
}

Makale Gönderme Tarihi: 13 Şubat 2015

Makale Kabul Tarihi: 22 Mayıs 2015

\begin{abstract}
ÖZ: Öğretmenler, öğrencilere kazandırılması gereken değerleri öncelikle kendi hayatlarında sergileyerek öğrencilere örnek olmalıdırlar. Bu sebeple, öğretmenlerin sahip oldukları değerlerin anlaşılmasının oldukça önemli olduğu düşünülmektedir. Bu araştırmanın amacı, öğretmen davranışlarının öğretmen görüşlerine göre değerler eğitimi açısından incelenmesidir. Araştırmada nitel araşıırma yöntemi benimsenmiş̧ir. Araştırmanın çalışma grubunu Düzce merkezde yer alan farklı okullardaki farklı branşlardan beş ilkokul, üç ortaokul ve dört lise öğretmeni oluşturmaktadır. Veriler yarı yapılandırılmış görüşme formu kullanılarak toplanmış ve içerik analizi yöntemiyle analiz edilmiştir. Veriler, araşıırmacılar tarafindan kodlanarak olumsuz öğretmen davranışları belirlenmiştir. Olumsuz öğretmen davranışları ana kategoriler altında toplanmış ve zedelenen değerler tespit edilmiştir. Ortaya çıkan sonuçlar, ilkokul, ortaokul ve lise öğretmenleri olarak tablolaştırılmıştır. Ayrıca, olumsuz öğretmen davranışları ve zedelenen değerlerin öğretim kademelerine göre karşıllaştırılması yapılmıştır. Bulgular ve yorumlardan hareketle olumsuz öğretmen davranışları sonucu; adalet, saygı-hoşgörü-samimiyet, alçak gönüllülük, doğruluk, ölçülülük, sorumluluk, merhamet-sabır, örnek olma, çalışkanlık-başarılı olma, fedakârlık-dayanışma değerlerinin zedelendiği tespit edilmiştir. Sonuçlara göre, öğretmenlerin değerleri zedeleyici davranışlarıyla ilgili birtakım öneriler geliştirilmiş̧tir.
\end{abstract}

Anahtar kelimeler: Değer, değerler eğitimi, öğretmen davranışları.

\section{Giriş}

Değer, "bir ulusun sahip olduğu sosyal, kültürel, ekonomik ve bilimsel değerlerini kapsayan maddi ve manevi ögelerin bütünü” olarak ifade edilebilir (Türk Dil Kurumu [TDK], 2014). Değerler, toplumun sosyo-kültürel ögelerine anlam veren en önemli ölçütlerdir (Özensel, 2003). Birey, değerler sayesinde neyin önemli olduğunu tanımlayarak, belirli bir durumu bir diğerine tercih etme eğilimi gösterir. Dolayısıyla değerler, davranış ve eylemleri yönlendiren, bireylerin farklı durumlardaki tavır ve tutumlarını şekillendiren ilke ve standartlardır. Değerler, bireyin onaylanmayan davranışlarını engelleme işlevi üstlenip kişileri toplumsal normlara uymaya yönelterek doğru davranışlar yapmalarına kaynaklık ederler. İdeal olarak olumlu değer ve tutumlar iyi ayarlanmış davranışlar ortaya koyarlar (Aktay \& Ekşi, 2009; Bektaş \& Nalçacı, 2012; Gül, 2013; Okumuş, 2010; Özdaş, 2013). Değer-davranış ilişkisi bir toplumun can damarı nispetinde önemlidir. Bu sebeple toplumların yaşayabilmesi ve varlıklarını devam ettirebilmesi sahip oldukları değerlere bağlı olup değerlerin gelecek nesillere aktarımı hayati bir öneme sahiptir.

Bireylerin değer oluşumları göz önüne alındığında birçok etmenden söz edilebilir; aile, okul, sosyal çevre ve medya (Akbaş, 2004; Yalar, 2010). Her birinin etki alanı iç içe geçmiş bulunmakla beraber bireyin karakterinin şekillendiği çağlarda en

\footnotetext{
*Bu makalenin bir kısmıYıldız International Conference on Educational Research and Social Studies 2014'te bildiri olarak sunulmuştur.

*** Sorumlu Yazar: Prof. Dr., Düzce Üniversitesi, Düzce, Türkiye, abdurrahmankilic@ duzce.edu.tr

*** Doktora Öğrencisi, Düzce Üniversitesi, Düzce, Türkiye, seyymasahin@gmail.com

*****Doktora Öğrencisi, Abant İzzet Baysal Üniversitesi, Bolu, Türkiye,ozlem_cap@yahoo.com

******Araş. Gör., Düzce Üniversitesi, Düzce, Türkiye, zeyneparseven@ duzce.edu.tr
} 
etkin rolü sosyal çevre ve okul üstlenmektedir çünkü okullar ailede kazanılan değerlerin içselleştirildiği, uygulandığı ve pekiştirildiği hatta yeni değerlerin kazanıldığı bir ortamdır (Keskin, 2008). Dolayısıyla değer aktarımı ailede başlayıp okul ve sosyal çevrede devam eden bir süreç olup, okullar bu sürecin en önemli basamağını teşkil etmektedirler.

Keskin (2008)'e göre eğitimin en önemli amacı toplumun değer yargılarını bir sonraki nesle aktarmaktır. Bu amaç “değerler eğitimi”ni zorunlu kılmaktadır. Değerler eğitimi son yıllarda gündemde olan bir konu olup 2004 y1lında öğretim programlarına girmiş bulunmaktadır. Her ne kadar programlarda "kazandırılması gereken değerler" adı altında yer alsalar da temelde değerler örtük bir biçimde aktarılmaktadır. Örtük program, sinıflarda ve okullarda öğrenme sürecinin birer parçası olan ve çoğu zaman farkına varılmadan bilgi, değer ve inançları bireye kazandıran çok güçlü bir araçtır (Akbaş, 2004; Doğanay \& Sarı, 2004; Sarı, 2007). Çocuklar okulda öğrenmeyi amaçladıkları ve amaçlamadıkları birçok şeyi gözlemlemekte ve gözledikleri her şey onların iyi, kötü, doğru ve yanlış konusunda anlayış geliştirmelerine katkıda bulunmaktadır (Çengelci, Hancı, \& Karaduman, 2013; Gençtürk, Akbaş, \& Kaymakçı, 2012).

Değer aktarımında çok önemli bir yere sahip olan okul kültürünün bir parçası olan ve öğrencilerle günlük rutinlerinde en fazla vakit geçiren öğretmenler, öğrenciler üzerinde en etkili olan grup olarak gözükmektedir. Bu durum öğretmenin sahip olduğu değerleri ve nitelikleri çok önemli kılmaktadır çünkü “öğretmen, kişilik nitelikleri ve bu niteliklerin çocukların zihinsel, duygusal ve sosyal gelişimi üzerine muhtemel etkilerine dayanan halihazırdaki mevcut bir psikolojik güçtür” (Bandura, 1969, aktaran, Sünbül, 1996).

Öğretmen bir öğretici olmakla beraber aynı zamanda toplumu aydınlatan, bilgi kaynağı, anne-baba, bahçıvan, heykeltıraş, danışman, rehber ve model olarak da tanımlanmaktadır (Okoro, 2011; Şahin, 2011; Yıldırım, Ünal, \&Çelik, 2011). Bu nedenle öğretmenlerin kişisel nitelikleri, mesleki niteliklerinin de önünde önem kazanmaktadır. Çocuklar kendi güdüleri kadar yetişkinlerin, akranlarının özellikle de öğretmenlerin rolleriyle özdeşlik kurarak tutum ve değer kazanmaktadırlar (Sünbül, 1996). Öğretmenlerin sınıfta ve okulda oluşturdukları kültür, neye önem verip vermedikleri, neyi iyi ya da kötü olarak algıladıkları öğrenciler için örtük olarak değerler eğitimini oluşturmaktadır (Doğanay, 2010).

Öğretmenlerin değerlerinin öğrenci davranışlarını etkilediğini gösteren birçok araştırma bulgusu vardır (Brophy \& Good, 1986; Dickinson, 1990, aktaran, Y1lmaz, 2009; Halstead \& Taylor, 2000; Yalar, 2010; Y1ldırım, 2009; Yiğittir \& Öcal, 2011). Öğretmenlerin bazı davranışlarının öğrenciler üzerindeki etkilerinin ne kadar önemli ve hayati oldukları öğrencilerin hayat boyu devam eden alışkanlıklarında ve değer yargılarında ortaya çıkmaktadır. Öğretmenler yalnızca bilgileriyle değil, her türlü davranış ve tutumlarıyla öğrencilere dolayısıyla topluma örnek olmalıdırlar. Öğretmen bir değer taşıyıcısı olarak sorumluluklarının farkında olmalı ve ideal değerleri üzerinde taşımayı birinci derecede önemsemelidir çünkü eğer öğretmen, öğretim faaliyetlerinde 
uygulanması istenilen değerlere sahip değilse, öğrencilerine iyi bir model olamadığı gibi öğrencilerde bulunan mevcut değerlerin körelmesine ve hatta ortadan kalkmasına bile sebep olabilecektir (Can, 2004; Çakıroğlu, 2013; Önen, 2012).

\section{Araştırmanın Amacı}

$\mathrm{Bu}$ çalışma, öğretmenlerin değerleri zedeleyen davranışlarını, dolayısıyla değer yargılarını yine öğretmenler gözüyle okumaya ve anlamaya çalışmak amacıyla ortaya konmuştur. Araştırmanın odağında, “Öğretmenlerin meslektaşlarında gördükleri olumsuz davranışlar ve bu davranışların zedelediği değerler nelerdir?” sorusu bulunmaktadir.

Araştırma sonunda cevaplanması amaçlanan sorular aşağıda verilmiştir.

- İlkokul öğretmenlerinin meslektaşlarında gördükleri olumsuz davranışlar ve bu davranışların zedelediği değerler nelerdir?

- Ortaokul öğretmenlerinin meslektaşlarında gördükleri olumsuz davranışlar ve bu davranışların zedelediği değerler nelerdir?

- Lise öğretmenlerinin meslektaşlarında gördükleri olumsuz davranışlar ve bu davranışların zedelediği değerler nelerdir?

- Öğretmenlerin meslektaşlarında gördükleri olumsuz davranışlar ve bu davranışların zedelediği değerler öğretim kademelerine göre nasıl farkl11ık göstermektedir?

\section{Yöntem}

\section{Araştırmanın Modeli}

Araştırmada nitel araştırma desenlerinden olgubilim deseni benimsenmiştir. Nitel araştırma, verilerin doğal ortamında gerçekçi ve bütüncül olarak toplanmasına katkı sağlayarak, insanların hayatlarını ve dünyalarını nasıl anlamlandırdıklarını ortaya koyar (Merriam, 2009; Yıldırım \& Şimşek, 2008). Olgubilim deseni, derinlemesine ve ayrıntılı bir anlayışa sahip olmadığımız, anlamını tam olarak kavrayamadığımız olguları araştırmayı amaçlar (Yıldırım \& Şimşek, 2008). Öğretmenlerin olumsuz davranışlarının hangi değerleri zedelediği bu araştırmanın odağını oluşturmaktadır. Bu kapsamda araştırmada ele alınan olgu “değerlerin zedelenmesi” olgusudur.

\section{Çalışma Grubu}

Araştırmanın çalışma grubu, nitel araştırmada amaçlı örnekleme yöntemlerinden biri olan maksimum çeşitlilik örneklemesine göre seçilmiştir. Olgubilim araştırmalarında veriler araştırmanın odaklandığı olguyu yaşayan ve bu olguyu dışa vurabilecek bireyler ya da gruplardan seçilmektedir. Bu bağlamda bu araştırmada ayrıntılı ve derinlemesine bilgi sağlanabilecek öğretmenlerle görüşmeler yapılmıştır. Araştırmanın çalışma grubunu Düzce merkezde yer alan farklı okullardaki farklı branşlardan beş ilkokul, üç ortaokul ve dört lise öğretmeni oluşturmaktadır. 


\section{Verilerin Toplanması}

Olgubilim deseninde temel veri toplama tekniği görüşmedir (Yıldırım \& Şimşek, 2008). Bu kapsamda bu araştırma verileri yarı yapılandırılmış görüşmeler aracılığıyla toplanmıştır. Yarı yapılandırılmış görüşmeler, görüşmeci tarafından algılanan dünyanın kendi düşünceleriyle anlatılmasına olanak sağlamaktadır (Merriam, 2009).

Literatür taraması sonrası öğretmenlerin kendi öğretim kademelerindeki meslektaşlarında gözlemlediği değerleri zedeleyici davranışları ortaya çıkarmayı amaçlayan görüşme soruları hazırlanmıştır. Görüşme soruları, uzman görüşüne sunulduktan sonra gerekli düzenlemeler yapılmış, görüşme formu uygulamaya hazır hâle getirilmiştir. Araştırmacılar, görüşme formunda yer alan soruları görüşmecilere tek tek yöneltmiş ve görüşmenin akışına bağlı olarak değişik sonda sorularla görüşmecilerin cevaplarını ayrıntılandırmalarını sağlamaya çalışmışlardır.

\section{Verilerin Analizi}

Veriler, içerik analizi yöntemi kullanılarak analiz edilmiştir. Görüşme yapılan ilkokul öğretmenleri İÖ1, İÖ2, İÖ3, İÖ4 ve İÖ5 şeklinde, ortaokul öğretmenleri OÖ1, OÖ2 ve OÖ3 şeklinde, lise öğretmenleri ise LÖ1, LÖ2, LÖ3 ve LÖ4 şeklinde kodlanmıştır.

Veriler üç araştırmacı tarafindan olumsuz öğretmen davranışları olarak kodlanmış ve sonrasında ortak olumsuz öğretmen davranışları belirlenmiştir. Ortaya çıkan sonuçlar, ilkokul öğretmenleri, ortaokul öğretmenleri ve lise öğretmenleri olarak ayrı ayrı tablolaştırılmıştır. Ayrıca, olumsuz öğretmen davranışları ve zedelenen değerlerin öğretim kademelerine göre karşılaştırılması yapılmıştır.

\section{Bulgular}

Öğretmenlerle yapılan görüşmelerden elde edilen verilerin analizi sonucu ortaya çıkan bulgular aşağıdaki şekilde dört başlık altında toplanmıştır:

- İlkokul öğretmenlerine göre olumsuz öğretmen davranışları ve zedelenen değerler

- Ortaokul öğretmenlerine göre olumsuz öğretmen davranışları ve zedelenen değerler

- Lise öğretmenlerine göre olumsuz öğretmen davranışları ve zedelenen değerler

- Olumsuz öğretmen davranışları ve zedelenen değerlerin öğretim kademelerine göre karşılaştırılması

\section{İlkokul Öğretmenlerine Göre Olumsuz Öğretmen Davranışları ve}

\section{Zedelenen Değerler}

İlkokul öğretmenlerinin görüşlerine göre ilkokul öğretmenlerinde görülen olumsuz davranışlar incelenmiş, bu davranışlar ana ve alt kategoriler şeklinde düzenlenmiş ve bu davranışların zedelediği değerler Tablo 1' de verilmiştir. 
Tablo 1

Illkokul Öğretmenlerine Göre Olumsuz Öğretmen Davranışları ve Zedelenen Değerler

\begin{tabular}{|c|c|c|}
\hline Zedelenen Değer & Ana Kategoriler & Alt Kategoriler \\
\hline \multirow{2}{*}{ Adalet } & $\begin{array}{l}\text { Öğrencileri değerlendirmede } \\
\text { adaletsizlik }\end{array}$ & $\begin{array}{l}\text { Sınav esnasına bazı öğrencilere hatırlatma } \\
\text { yapmak }\end{array}$ \\
\hline & Öğrencilere karşı ön yargılı olmak & $\begin{array}{l}\text { Öğrencilerin öğrenme kapasiteleri } \\
\text { hakkında ön yargılı olmak }\end{array}$ \\
\hline Saygı & İdareyle olumsuz ilişkiler & İdare ile iyi iletişim kuramamak \\
\hline \multicolumn{3}{|l|}{ Hoşgörü } \\
\hline \multicolumn{3}{|l|}{ Samimiyet } \\
\hline Sorumluluk & $\begin{array}{l}\text { Dersle ilgili sorumluluklarının hakkını } \\
\text { vermemek }\end{array}$ & Derse vaktinde girip çıkmamak \\
\hline \multirow{3}{*}{$\begin{array}{l}\text { Merhamet } \\
\text { Sabır }\end{array}$} & \multirow{3}{*}{$\begin{array}{l}\text { Öğrencilere kötü muamelede } \\
\text { bulunmak }\end{array}$} & Öğrencilere hakaret etmek \\
\hline & & Öğrencilere sözel şiddet uygulamak \\
\hline & & Öğrencileri aşağılamak \\
\hline \multirow{3}{*}{$\begin{array}{l}\text { Fedakarlık } \\
\text { Dayanışma }\end{array}$} & Ekstra sorumluluk almaktan kaçınmak & Ders dışı görev almak istememek \\
\hline & & Öğrencilere ders dışı vakit ayırmamak \\
\hline & $\begin{array}{l}\text { Meslektaşlarıyla dayanışma içinde } \\
\text { olmamak }\end{array}$ & $\begin{array}{l}\text { Meslektaşlarıyla mesleki paylaşımda } \\
\text { bulunmamak }\end{array}$ \\
\hline
\end{tabular}

İlkokul öğretmenlerinin görüşlerine göre ilkokul öğretmenlerinde görülen olumsuz davranışlar incelendiğinde bu davranışların beş farklı değer grubunu zedelediği tespit edilmiştir. Bu değerler adalet, saygı-hoşgörü-samimiyet, sorumluluk, merhametsabır ve fedakarlık-dayanışmadır.

İÖ1 kodlu öğretmen sorumluluk değeriyle ilgili düşüncelerini, "Öğretmen derslere giriş çıkışlarına dikkat etmeli. Nasıl vaktinde çıkıyorsa o hassasiyeti derse girerken de göstermeli. Bu konuda sıkıntı yaşanıyor, bu beni rahatsız ediyor. "şeklinde ifade etmiştir. İÖ3 kodlu öğretmenin "Benim en ă̆ır lafım kuşbeyinli. Geçen bir ögrenciye söyledim başladı ağlamaya. Niye ağllyorsun gücüne mi gitti dedim. O kadar hassassan o yanlışı yapmamalıydın, ancak kuşlar yapar o yanlışı dedim." şeklindeki sözleri merhamet-sabır değerini zedeleyen olumsuz öğretmen davranışlarına iyi bir örnek teşkil etmektedir.

İÖ5 kodlu öğretmen "Paylaşımcılık \%100 var dersek yalan olur. Yaptıklarını saklayan arkadaşlar var." diyerek meslektaşlarıyla aralarında yeterli paylaşımın olmadığını ifade etmiştir. Bu davranışın da fedakarlık ve dayanışma değerini zedelediği tespit edilmiştir. 


\section{Ortaokul Öğretmenlerine Göre Olumsuz Öğretmen Davranışları ve Zedelenen Değerler}

Ortaokul öğretmenlerinin görüşlerine göre ortaokul öğretmenlerinde görülen olumsuz davranışlar incelenmiş, bu davranışlar ana ve alt kategoriler şeklinde düzenlenmiş ve bu davranışların zedelediği değerler Tablo 2' de verilmiştir.

Tablo 2

Ortaokul Öğretmenlerine Göre Olumsuz Öğretmen Davranıslart ve Zedelenen Değerler

\begin{tabular}{|c|c|c|}
\hline Zedelenen Değer & Ana Kategoriler & Alt Kategoriler \\
\hline \multirow{7}{*}{ Adalet } & Öğrencilere ayrımcıllk & $\begin{array}{l}\text { Öğrencilere veli profillerine göre ayrımcılık } \\
\text { yapmak }\end{array}$ \\
\hline & & $\begin{array}{l}\text { Öğrencilere sosyo-ekonomik durumlarına } \\
\text { göre ayrımcılık yapmak }\end{array}$ \\
\hline & & $\begin{array}{l}\text { Öğrencilere siyasi görüşlerine göre } \\
\text { ayrımcılık yapmak }\end{array}$ \\
\hline & & $\begin{array}{l}\text { Öğrencilere başarı durumlarına göre } \\
\text { ayrımcılık yapmak }\end{array}$ \\
\hline & $\begin{array}{l}\text { Öğrencileri değerlendirmede } \\
\text { adaletsizlik }\end{array}$ & $\begin{array}{l}\text { Kopya çekmeye karşı olumlu tutum } \\
\text { geliştirmek }\end{array}$ \\
\hline & & $\begin{array}{l}\text { Kopya çekmeye karşı tepkilerde tutarsız } \\
\text { olmak }\end{array}$ \\
\hline & & Not vermede adaletsiz davranmak \\
\hline \multirow{12}{*}{$\begin{array}{l}\text { Saygı } \\
\text { Hoşgörüu } \\
\text { Samimiyet }\end{array}$} & Meslektaşlarıyla olumsuz ilişkiler & Meslektaşlarıyla sürtüşmek \\
\hline & & $\begin{array}{l}\text { Meslektaşlarının farklı görüşlerine saygı } \\
\text { göstermemek }\end{array}$ \\
\hline & & Meslektaşlarıyla iyi iletişim kuramamak \\
\hline & & Meslektaşlarını dışlamak \\
\hline & & Meslektaşlarını kıskanmak \\
\hline & & Meslektaşlarının dedikodusunu yapmak \\
\hline & Öğrencilerle olumsuz ilişkiler & $\begin{array}{l}\text { Öğrencilerle iyi iletişim kuramamak } \\
\text { Öğrencilerle empati kuramamak }\end{array}$ \\
\hline & Velilerle olumsuz ilişkiler & Velilerle ilişkilerde önyargılı olmak \\
\hline & & Velileri küçümsemek \\
\hline & & Velilerle ilişkilerde samimiyetsiz olmak \\
\hline & İdareyle olumsuz ilişkiler & $\begin{array}{l}\text { İdarecilerin verdikleri görevleri karşıllkk } \\
\text { bekleyerek yapmak }\end{array}$ \\
\hline & & $\begin{array}{l}\text { İdareye görüşlerini ifade ederken samimi } \\
\text { davranmamak }\end{array}$ \\
\hline \multirow{2}{*}{$\begin{array}{l}\text { Alçak } \\
\text { Gönüllüllük }\end{array}$} & Kendini kusursuz görmek & Mesleki olarak kendini kusursuz görmek \\
\hline & & Öğrencilerin başarısızlıklarını \\
\hline
\end{tabular}




\begin{tabular}{|c|c|c|}
\hline & & sahiplenmemek \\
\hline & Eleştiriye açık olmamak & $\begin{array}{l}\text { Meslektaşlarının eleştirilerine açık olmamak } \\
\text { Velilerin eleştirilerine açık olmamak }\end{array}$ \\
\hline \multirow{4}{*}{ Ölçülülük } & Kılık kıyafette ölçüsüzlük & Mini etekle derse girmek \\
\hline & & Dekolteli kıyafetle derse gelmek \\
\hline & & Yırtık kotla derse gelmek \\
\hline & $\begin{array}{l}\text { Öğrencilerle ilişkilerde } \\
\text { ölçüsüzlük }\end{array}$ & Öğrenciler üzerinde aşırı disiplin sağlamak \\
\hline \multirow{4}{*}{ Sorumluluk } & Dersle ilgili sorumluluklarının & Derse vaktinde girip çıkmamak \\
\hline & hakkını vermemek & Derste telefonla konuşmak \\
\hline & $\begin{array}{l}\text { Nöbetle ilgili sorumluluklarının } \\
\text { hakkını vermemek }\end{array}$ & Nöbetin hakkını vermemek \\
\hline & Öz denetim sağlayamamak & Öz denetim sağlayamamak \\
\hline \multirow{8}{*}{$\begin{array}{l}\text { Merhamet } \\
\text { Sabir }\end{array}$} & Öğrencilere kötü muamelede & Öğrencilere sözel şiddet uygulamak \\
\hline & bulunmak & Öğrencileri aşağılamak \\
\hline & & Öğrencileri küçümsemek \\
\hline & & Öğrencilere fiziksel şiddet uygulamak \\
\hline & & Öğrencilere hakaret etmek \\
\hline & & Öğrencilere karşı öfkesini kontrol edememek \\
\hline & & Öğrencileri dersten çıkarmak \\
\hline & & Öğrencileri kendi işlerinde kullanmak \\
\hline \multirow{2}{*}{ Örnek Olma } & $\begin{array}{l}\text { Sigara konusunda kötü örnek } \\
\text { olmak }\end{array}$ & Sigara konusunda kötü örnek olmak \\
\hline & $\begin{array}{l}\text { Okul dışındaki davranışlarına } \\
\text { özen göstermemek }\end{array}$ & $\begin{array}{l}\text { Okul dışındaki davranışlarına özen } \\
\text { göstermemek }\end{array}$ \\
\hline \multirow{4}{*}{$\begin{array}{l}\text { Çalışkanlık } \\
\text { Başarılı Olma }\end{array}$} & Mesleki olarak kendini & Mesleki tükenmişlik \\
\hline & geliştirmemek & Mesleki yeniliklere açık olmamak \\
\hline & & Teknolojik yenilikleri takip etmemek \\
\hline & Sınıfı iyi yönetememek & Sınıfi iyi yönetememek \\
\hline \multirow{3}{*}{$\begin{array}{l}\text { Fedakarlık } \\
\text { Dayanışma }\end{array}$} & $\begin{array}{l}\text { Ekstra sorumluluk almaktan } \\
\text { kaçınmak }\end{array}$ & Ders dişı görev almak istememek \\
\hline & $\begin{array}{l}\text { Meslektaşlarıyla dayanışma } \\
\text { içinde olmamak }\end{array}$ & $\begin{array}{l}\text { Meslektaşlarıyla mesleki paylaşımda } \\
\text { bulunmamak }\end{array}$ \\
\hline & & Meslektaşları ile yardımlaşmadan kaçınmak \\
\hline
\end{tabular}

Ortaokul öğretmenlerinin görüşlerine göre ortaokul öğretmenlerinde görülen olumsuz davranışlar incelendiğinde bu davranışların dokuz farklı değer grubunu zedelediği tespit edilmiştir. $\mathrm{Bu}$ değerler adalet, sayg1-hoşgörü-samimiyet, alçak 
gönüllülük, ölçülülük, sorumluluk, merhamet-sabır, örnek olma, çalışkanlık-başarılı olma ve fedakarlık-dayanışmadır.

OÖ1 kodlu öğretmenin "İnsanız sonuçta, etkilenmiyoruz dersek yalan olur. Çok düzgün bir çocuksa, davranışları falan çok düzgünse, yazılı kağıdını okurken 3-5 puan vermek konusunda etkilenebiliyor insan.” şeklindeki sözleri ile OÖ3 kodlu öğretmenin "Evet tabi ki var kiskançlık. Bizim okulda sınıfçılarla branşçılar arasında var kıskançlık. Daha çok bayan öğretmenler birbirlerini kıskanıyorlar. Aynı branştan olan ögretmenler arasında da çok oluyor kıskançlık. Öğretmenler birbirlerinin başarılarını kıskanıyorlar." şeklindeki sözlerinin, adalet değerinin zedelendiğinin açık bir göstergesi olduğu düşünülmektedir.

OÖ2 kodlu öğretmenin "Kafan hiç mi çalışmıyor? gibi sözler olur. Ben de söylüyorumdur. Söylemiyorum diyen kesinlikle yalan söyler." şeklindeki ifadeleri merhamet-sabır değerlerini zedelediği düşünülen öğrencileri küçümseme ve öğrencileri aşağılama davranışlarının ortaya konulduğunun bir göstergesidir.

\section{Lise Öğretmenlerine Göre Olumsuz Öğretmen Davranışları ve Zedelenen Değerler}

Lise öğretmenlerinin görüşlerine göre lise öğretmenlerinde görülen olumsuz davranışlar incelenmiş, bu davranışlar ana ve alt kategoriler şeklinde düzenlenmiş ve bu davranışların zedelediği değerler Tablo 3' de verilmiştir.

Tablo 3

Lise Öğretmenlerine Göre Olumsuz Öğretmen Davranışlart ve Zedelenen Değerler

\begin{tabular}{|c|c|c|}
\hline Zedelenen Değer & Ana Kategoriler & Alt Kategoriler \\
\hline \multirow{6}{*}{ Adalet } & \multirow[t]{2}{*}{ Öğrencilere ayrımcılık } & $\begin{array}{l}\text { Öğrencilere başarı durumlarına göre ayrımcılık } \\
\text { yapmak }\end{array}$ \\
\hline & & $\begin{array}{l}\text { Öğrencilere cinsiyetlerine göre ayrımcıllk } \\
\text { yapmak }\end{array}$ \\
\hline & \multirow{4}{*}{$\begin{array}{l}\text { Öğrencileri değerlendirmede } \\
\text { adaletsizlik }\end{array}$} & Kopya çekmeye karşı tolerans göstermek \\
\hline & & Not vermede adaletsiz davranmak \\
\hline & & Notları gayri resmi yükseltmek \\
\hline & & Sınav sorularını önceden vermek \\
\hline \multirow{8}{*}{$\begin{array}{l}\text { Saygı } \\
\text { Hoşgörü } \\
\text { Samimiyet }\end{array}$} & \multirow{6}{*}{$\begin{array}{l}\text { Meslektaşlarıyla olumsuz } \\
\text { ilişkiler }\end{array}$} & Meslektaşlarını dışlamak \\
\hline & & Meslektaşlarını kıskanmak \\
\hline & & Meslektaşlarının dedikodusunu yapmak \\
\hline & & Meslektaşları arasında laf taşımak \\
\hline & & Meslektaşlarıyla iyi iletişim kuramamak \\
\hline & & Meslektaşlarına karşı ön yargılı olmak \\
\hline & \multirow[t]{2}{*}{ Velilerle olumsuz ilişkiler } & Velilerle ilişkilerde samimiyetsiz olmak \\
\hline & & Velilerle iyi iletișim kuramamak \\
\hline
\end{tabular}




\begin{tabular}{|c|c|c|}
\hline & İdareyle olumsuz ilişkiler & $\begin{array}{l}\text { İdareye görüşlerini ifade ederken samimi } \\
\text { davranmamak }\end{array}$ \\
\hline & & İdare ile iyi iletişim kuramamak \\
\hline \multirow{2}{*}{ Alçak Gönüllülük } & Kendini kusursuz görmek & Mesleki olarak kendini kusursuz görmek \\
\hline & Eleştiriye açık olmamak & Meslektaşlarının eleştirilerine açık olmamak \\
\hline Doğruluk & Yalan söylemek & Yalan söylemek \\
\hline \multirow{4}{*}{ Ölçülülük } & Kılık kıyafette ölçüsüzlük & Dekolteli kıyafetle derse gelmek \\
\hline & & Kılık kıyafet kurallarına uymamak \\
\hline & Öğrencilerle ilişkilerde & Öğrencilerle ilişkilerde aşırı samimi olmak \\
\hline & ölçüsüzlük & Öğrenciler üzerinde aşırı disiplin sağlamak \\
\hline \multirow{6}{*}{ Sorumluluk } & Dersle ilgili sorumluluklarının & Derse vaktinde girip çıkmamak \\
\hline & hakkını vermemek & Ders defterini imzalamamak \\
\hline & & Derste at yarışı oynamak \\
\hline & & Yoklamayı vaktinde almamak \\
\hline & Nöbetle ilgili & Nöbete geç gelmek \\
\hline & $\begin{array}{l}\text { sorumluluklarının hakkını } \\
\text { vermemek }\end{array}$ & Nöbetin hakkını vermemek \\
\hline \multirow{4}{*}{$\begin{array}{l}\text { Merhamet } \\
\text { Sabır }\end{array}$} & Öğrencilere kötü muamelede & Öğrencileri aşağılamak \\
\hline & bulunmak & Öğrencilere hakaret etmek \\
\hline & & Öğrencilere küfür etmek \\
\hline & & Öğrencileri dersten çıkarmak \\
\hline \multirow{2}{*}{ Örnek Olma } & $\begin{array}{l}\text { Sigara konusunda kötü örnek } \\
\text { olmak }\end{array}$ & Sigara konusunda kötü örnek olmak \\
\hline & $\begin{array}{l}\text { Okul dışındaki davranışlarına } \\
\text { özen göstermemek }\end{array}$ & Okul dışındaki davranışlarına özen göstermemek \\
\hline \multirow{4}{*}{$\begin{array}{l}\text { Çalışkanlık } \\
\text { Başarılı Olma }\end{array}$} & Mesleki olarak kendini & Mesleki tükenmişlik \\
\hline & geliştirmemek & Mesleki yeniliklere açık olmamak \\
\hline & & Teknolojik yenilikleri takip etmemek \\
\hline & Sınıfı iyi yönetememek & Sınıfı iyi yönetememek \\
\hline \multirow{3}{*}{$\begin{array}{l}\text { Fedakarlık } \\
\text { Dayanışma }\end{array}$} & Ekstra sorumluluk almaktan & Ders dişı görev almak istememek \\
\hline & kaçınmak & Öğrencilere ders dışı vakit ayırmamak \\
\hline & $\begin{array}{l}\text { Meslektaşlarıyla dayanışma } \\
\text { içinde olmamak }\end{array}$ & $\begin{array}{l}\text { Meslektaşlarıyla mesleki paylaşımda } \\
\text { bulunmamak }\end{array}$ \\
\hline
\end{tabular}

Lise öğretmenlerinin görüşlerine göre lise öğretmenlerinde görülen olumsuz davranışlar incelendiğinde bu davranışların on farklı değer grubunu zedelediği tespit edilmiştir. Bu değerler adalet, sayg1-hoşgörü-samimiyet, alçak gönüllülük, doğruluk, ölçülülük, sorumluluk, merhamet-sabır, örnek olma, çalışkanlık-başarılı olma ve fedakarlık-dayanışmadır. 
LÖ1 kodlu öğretmenin "Okulumuzun öğretmenlerinin bir kısmı yaşlı. Karşılarındaki öğrenciler ise dijital çağın çocukları. Çocuklar facebook kullanıyor, sosyal paylaşım sitelerinden sürekli birbirleri ile iletişim içerisindeler. Öğretmenlerin böyle bir durumu yok tabi. Zaten bu hocalar internete notlart bile girerken bizden yardım alıyorlar." şeklindeki sözleri, öğretmenlerin teknolojik yenilikleri takip etmediklerinin bir göstergesi olup bu durumun çalışkanlık-başarılı olma değerini zedelediği düşünülmektedir.

LÖ2 kodlu öğretmen ölçülülük değerini zedeleyen olumsuz davranışlarla ilgili "Öğretmen öğrencisiyle ilişkide sınırı bilmeli. Gereksiz muhabbetler beni rahatsız ediyor. Bunu erkekler daha fazla yapıyor. Öğrencilerimden duyuyorum espriyle karışık laf sokmalar oluyor." şeklinde ifadeler kullanmıştır.

\section{Olumsuz Öğretmen Davranışları ve Zedelenen Değerlerin Öğretim Kademelerine Göre Karşılaştırılması}

Farklı öğretim kademelerinde görev yapan ilkokul, ortaokul, lise öğretmenlerinin görüşlerine göre olumsuz öğretmen davranışları ve zedelenen değerler araştırmacılar tarafindan karşılaştırılmış ve Tablo 4'te sunulmuştur.

Tablo 4

Olumsuz Öğretmen Davranışları ve Zedelenen Değerlerin Öğretim Kademelerine Göre Karşılaştırılması

\begin{tabular}{|c|c|c|c|c|}
\hline $\begin{array}{c}\text { Zedelenen } \\
\text { Değerler }\end{array}$ & $\begin{array}{c}\text { Olumsuz Öğretmen Davranışları Ana } \\
\text { Kategoriler }\end{array}$ & İlkokul & Ortaokul & Lise \\
\hline \multirow{3}{*}{ Adalet } & Öğrencilere ayrımcılık & & $\mathbf{x}$ & $\mathbf{x}$ \\
\hline & Öğrencilere karşı ön yargılı olmak & $\mathbf{x}$ & & \\
\hline & Öğrencileri değerlendirmede adaletsizlik & $\mathbf{x}$ & $\mathbf{x}$ & $\mathbf{x}$ \\
\hline \multirow{4}{*}{$\begin{array}{l}\text { Saygı } \\
\text { Hoşgörü } \\
\text { Samimiyet }\end{array}$} & Öğrencilerle olumsuz ilişkiler & & $\mathbf{x}$ & \\
\hline & Meslektaşlarıyla olumsuz ilişsiler & & $\mathbf{x}$ & $\mathbf{x}$ \\
\hline & Velilerle olumsuz ilişkiler & & $\mathbf{x}$ & $\mathbf{x}$ \\
\hline & İdareyle olumsuz ilişkiler & $\mathbf{x}$ & $\mathbf{x}$ & $\mathbf{x}$ \\
\hline \multirow{2}{*}{$\begin{array}{l}\text { Alçak } \\
\text { Gönüllülülk }\end{array}$} & Kendini kusursuz görmek & & $\mathbf{x}$ & $\mathbf{x}$ \\
\hline & Eleştiriye açık olmamak & & $\mathbf{x}$ & $\mathbf{x}$ \\
\hline Doğruluk & Yalan söylemek & & & $\mathbf{x}$ \\
\hline \multirow{2}{*}{ Ölçülülü̈k } & Kılık kıyafette ölçüsüzlük & & $\mathbf{x}$ & $\mathbf{x}$ \\
\hline & Öğrencilerle ilişkilerde ölçüsüzlük & & $\mathbf{x}$ & $\mathbf{x}$ \\
\hline Sorumluluk & Dersle ilgili sorumluluklarının hakkını & $\mathbf{x}$ & $\mathbf{x}$ & $\mathbf{x}$ \\
\hline
\end{tabular}




\begin{tabular}{|c|c|c|c|c|}
\hline & \multicolumn{4}{|l|}{ vermemek } \\
\hline & $\begin{array}{l}\text { Nöbetle ilgili sorumluluklarının hakkını } \\
\text { vermemek }\end{array}$ & & $\mathbf{x}$ & $\mathbf{x}$ \\
\hline & Öz denetim sağlayamamak & & $\mathbf{x}$ & \\
\hline $\begin{array}{l}\text { Merhamet } \\
\text { Sabır }\end{array}$ & Öğrencilere kötü muamelede bulunmak & $\mathbf{x}$ & $\mathbf{x}$ & $\mathbf{x}$ \\
\hline \multirow{2}{*}{ Örnek Olma } & Sigara konusunda kötü örnek olmak & & $\mathbf{x}$ & $\mathbf{x}$ \\
\hline & $\begin{array}{l}\text { Okul dışındaki davranışlarına özen } \\
\text { göstermemek }\end{array}$ & & $\mathbf{x}$ & $\mathbf{x}$ \\
\hline \multirow{2}{*}{$\begin{array}{l}\text { Çalışkanlık } \\
\text { Başarılı Olma }\end{array}$} & Mesleki olarak kendini geliştirmemek & & $\mathbf{x}$ & $\mathbf{x}$ \\
\hline & Sınıfı iyi yönetememek & & $\mathbf{x}$ & $\mathbf{x}$ \\
\hline \multirow{2}{*}{$\begin{array}{l}\text { Fedakarlık } \\
\text { Dayanışma }\end{array}$} & Ekstra sorumluluk almaktan kaçınmak & $\mathbf{x}$ & $\mathbf{x}$ & $\mathbf{x}$ \\
\hline & Meslektaşlarıyla dayanışma içinde olmamak & $\mathbf{x}$ & $\mathbf{x}$ & $\mathbf{x}$ \\
\hline
\end{tabular}

Adalet değerini zedeleyen öğrencilere ayrımcılık davranışının, ortaokul ve lise kademelerindeki öğretmenlerde bulunduğu görülürken, ilkokul öğretmenlerinde bulunmadığ1 görülmektedir. Öğrencilere karşı ön yargılı olma davranış1 sadece ilkokul öğretmenlerinde bulunurken; öğrencileri değerlendirmede adaletsizlik davranışı tüm kademelerdeki öğretmenlerde bulunmaktadır.

Sayg1-Hoşgörü-Samimiyet değerini zedeleyen öğrencilerle olumsuz ilişkiler davranışının sadece ortaokul öğretmenlerinde bulunduğu görülürken; meslektaşlarıyla olumsuz ilişkilerin ve velilerle olumsuz ilişkilerin ortaokul ve lise kademelerindeki öğretmenlerde bulunduğu görülmektedir. İdareyle olumsuz ilişkiler ise her kademedeki öğretmenlerde bulunmaktadır.

Alçak gönüllülük değerini zedeleyen kendini kusursuz görmek ve eleştiriye açık olmamak davranışlarının ortaokul ve lise kademelerindeki öğretmenlerde bulunduğu görülmektedir. Alçak gönüllülük değerini zedeleyen bu davranışlara ilkokul öğretmenlerinde rastlanmamıştır.

Doğruluk değerini zedeleyen yalan söyleme davranışı sadece lise öğretmenlerinde görülürken,LÖ3 kodlu öğretmenin “Öğretmen bazen pembe yalanlar söyleyebiliyorlar. Bunlar genelde velilerle ilişkiler sırasında oluyor. Veliye herşey aynen aksettirilemiyor. Bu durumda ögretmen pembe yalanlara başvurabiliyor." şeklindeki sözleri bu durumu destekler niteliktedir.

Ölçülülük değerini zedeleyen k1lık kıyafette ölçüsüzlük ve öğrencilerle ilişsilerde ölçüsüzlük davranışları, ilkokul öğretmenlerinde görülmezken diğer kademelerdeki öğretmenlerde görülmektedir.

Sorumluluk değerini zedeleyen öz denetim sağlayamama davranışının sadece ortaokul öğretmenlerinde bulunduğu görülürken, nöbetle ilgili sorumluluklarının 
hakkını vermeme davranışının ortaokul ve lise öğretmenlerinde bulunduğu ve dersle ilgili sorumluluklarının hakkını vermeme davranışının tüm kademelerdeki öğretmenlerde bulunduğu görülmektedir.

Merhamet-sabır değerini zedeleyen öğrencilere kötü muamelede bulunma davranışı ve fedakarlık-dayanışma değerini zedeleyen ekstra sorumluluk almaktan kaçınma ve meslektaşlarıyla dayanışma içinde olmama davranışlarının tüm kademelerdeki öğretmenlerde bulunduğu görülmektedir.

Örnek olma değerini zedeleyen sigara konusunda kötü örnek olma ve okul dışındaki davranışlarına özen göstermeme davranışları ve çalışkanlık-başarılı olma değerini zedeleyen mesleki olarak kendini geliştirmeme ve sınıfi iyi yönetememe davranışları ilkokul öğretmenlerinde görülmezken diğer kademelerdeki öğretmenlerde görülmektedir.

\section{Sonuç ve Tartışma}

İlkokul öğretmenlerinin meslektaşlarında gözlemlediği olumsuz davranışların adalet, saygı-hoşgörü-samimiyet, sorumluluk, merhamet-sabır, fedakarlık-dayanışma değerlerini zedelediği; ortaokul öğretmenlerinin meslektaşlarında gözlemlediği olumsuz davranışların adalet, saygı-hoşgörü-samimiyet, alçak gönüllülük, ölçülülük, sorumluluk, merhamet-sabır, örnek olma, çalışkanlık-başarılı olma, fedakarlık-dayanışma değerlerini zedelediği; lise öğretmenlerinin meslektaşlarında gözlemlediği olumsuz davranışların ise adalet, sayg1-hoşgörü-samimiyet, alçak gönüllülük, doğruluk, ölçülülük, sorumluluk, merhamet-sabır, örnek olma, çalışkanlık-başarılı olma, fedakarlık-dayanışma değerlerini zedelediği tespit edilmiştir.

Genel olarak bakıldığında ilkokul öğretmenlerinde görülen olumsuz öğretmen davranışları beş farklı değer grubunu zedelerken, ortaokul öğretmenlerinde görülen olumsuz öğretmen davranışlarının dokuz farklı değer grubunu ve lise öğretmenlerinde görülen olumsuz öğretmen davranışlarının ise on farklı değer grubunu zedelediği görülmektedir. Bu durum öğretim kademeleri arttıkça zedelenen değerlerin de arttı̆̆ sonucunu ortaya koymaktadır.

Araştırma bulguları; fiziksel görünüm, sosyo-ekonomik düzey, cinsiyet ve başarı durumuna göre öğrencilere ayrımcılık davranışının sıklıkla sergilendiğini göstermektedir. Adalet değerini zedeleyen bu durumun öğrenciler üzerinde yaşam boyu kalıcı izler bırakabileceği yapılan araştırmalarla ortaya konmaktadır (Çalışkan, Işık, \& Saygın, 2013; Keith-Spiegel,Wittig, Perkins, Balogh, \& Whitley, 1993; Öztürk, Koç, \& Şahin, 2002).

Özellikle ortaokul ve lise öğretmenlerinin meslektaşlarıyla, öğrencilerle, velilerle ve idare ile olumsuz ilişkiler içinde olabildikleri görülmektedir. Sayg1-hoşgörüsamimiyet değerleriyle bağdaşmayan bu durum, öğretmenlerin insani ilişkilerinde eksikliklerinin bulunduğunun bir göstergesidir. Halbuki öğretmenlik, insan ilişkileri üzerine kurulu bir meslek olup bir öğretmenin öğrencilerini anlayabilmesi, kendini doğru bir şekilde ifade edebilmesi ve insanlarla etkili iletişim kurabilmesi öğretmenin mesleki sosyalizasyonunu belirleyen güçlerdir. İletişim algıları yüksek olan 
öğretmenlerin sorunları daha yapıcı biçimde çözeceği düşünülmektedir (Çevik, 2011; Çubukçu \& Girmen, 2008; Pehlivan, 2005).

Doğruluk değerini zedeleyen yalan söyleme davranışı ilkokul ve ortaokul öğretmenlerinde görülmezken lise öğretmenlerinde ortaya çıkmıştır. Bir öğretmende kesinlikle bulunmaması gereken böyle bir davranışın ortaya çıkması çok düşündürücüdür. Öğretmen doğru sözlü olmall, verdiği söz ve vaatlere her şartta uymalı, yapamayacağı şeyleri söylememeli, söylediyse mutlaka yapmalıdır. Öğretmen, öğrencinin güvenini kaybetmekten korkmalı, öğrenci öğretmenini, tanıdığı en güvenilir insanlardan biri olarak bilmelidir (Y1lmaz, 2012). İdeal bir öğretmenin sorumluluklarını azami ölçüde yerine getiren kişi olması gerekirken yapılan bu araştırma öğretmenlerin sorumluluklarını tam anlamıyla yerine getirmedikleri sonucunu da ortaya çıkarmıştır.

Eğitim sevgiyle başlar. Başarı ancak öğrenciyi sevmek ve ona dersi sevdirmekle mümkündür. Sınıf içinde demokratik bir ortamın oluşması için öğretmen hoşgörülü olmalı, öğrencisine asla fiziksel ya da sözel şiddet uygulamamalıdır. Öğretmen bir devlet memurudur ve kendisine çizilen sınırlar içinde görevini yapmalıdır (Yılmaz, 2005; Yılmaz, 2012). Fakat araştırmanın sonuçlarına bakıldığında öğretmenlerin öğrencilere sözel ve fiziksel şiddet uygulama, öğrencileri aşağılama, öğrencileri küçümseme, öğrencilere hakaret etme gibi olumsuz davranışları sıklıkla yaptığı ve bu durumun da merhamet ve sabır değerlerini zedelediği görülmektedir.

Ortaokul ve lise öğretmenlerinin bir kısmının okul dışındaki davranışlarına çok dikkat etmedikleri ve bu bağlamda öğrencilere olumsuz örneklik teşkil ettikleri, kılık kıyafetlerinde ve öğrencilerle ilişkilerinde ölçülü olmadıkları da araştırma sonuçları arasındadır. Halbuki öğretmenlerden içinde yaşadıkları toplumun olumlu yönde değişmesine ve ilerlemesine yardımcı olmaları ve topluma örnek olmaları beklenmektedir (Çelikten \& Can, 2003). Son yıllarda yapılan araştırmalar öğretmenlerin teknolojiyi etkin kullanamadıkları ve mesleki yeniliklere açık olmadıkları gerçeğini vurgulamaktadır (Avc1 \& Seferoğlu, 2011; Erdemir, Bakırc1, \& Eyduran, 2009; Yaylac1, 2013; Yüksel \& Adıgüzel, 2012). Yapılan bu araştırma da bunu destekler nitelikte olup öğretmenlerin mesleki olarak kendilerini geliştirmeye isteklerinin az olduğunu ve bu durumun çalışkanlık ve başarılı olma değeriyle bağdaşmadığını göstermektedir.

Öğretmenler mesleki bilgilerini birbirleriyle paylaşmalı, takım çalışması yapmalı, meslektaşlarıyla açık iletişim kurmalıdırlar (Ateş, 2012). Lakin araştırma sonuçları tüm kademelerdeki öğretmenlerin ekstra sorumluluk almaktan kaçındıklarını ve meslektaşlarıyla dayanışma içinde olmadıklarını göstermektedir. Bu durum fedakarlık ve dayanışma değerleriyle bağdaşmamaktadır.

\section{Öneriler}

Araştırma sonuçlarına göre aşağıdaki öneriler geliştirilmiştir:

- Gelecek nesillere kazandırılması beklenen değerler öncelikle bu değerleri gelecek nesillere aktaracak olan öğretmen adaylarına öğretmen yetiştirme sürecinde kazandırılmalıdır. 
- Öğretmenler, değerlerle ilgili fikir birliği içinde olmalı, kendi yaptıkları olumsuz davranışlarını gözden geçirmeli ve kendi aralarında yapacakları çalışmalarla birbirlerini olumlu yönde motive ederek olumlu bir okul kültürü oluşturmaya çalışmalıdırlar.

- Öğretmenler öğretim programlarında yer alan ve öğrencilere kazandırılması gereken değerler hakkında bilgi sahibi olmalı ve bunları ders içerisinde örtük olarak öğrencilere kazandırmaya çalışmalıdırlar.

- Öğretim kademelerine göre olumsuz öğretmen davranışlarının farklılık göstermesinin nedenleri araştırılarak bu konuda öneriler geliştirilebilir.

- Ayrıca, bu çalışma farklı sosyo-kültürel özellik gösteren bölgelerde görev yapan öğretmenler üzerinde de uygulanabilir. 


\section{Kaynakça}

Akbaş, O. (2004). Türk milli ĕgitim sisteminin duyuşsal amaçlarının ilköğretim II. kademedeki gerçekleşme derecesinin dĕ̌gerlendirilmesi. (Yayımlanmamış doktora tezi). Gazi Üniversitesi, Ankara.

Aktay, A., \& Ekşi, H. (2009). Yönetici ve öğretmenlerin değer tercihleri ile örgütsel vatandaşlık davranışları arasındaki ilişki. İş Ahlakı Dergisi, 2(3), 19-65.

Ateş, N. (2012). Öğretmenlikte meslek ahlak1 ve mesleki değerler. Ĕğitim ve İnsani Bilimler Dergisi, 3(6), 3-18.

Avc1, Ü.,\& Seferoğlu, S. S. (2011). Bilgi toplumunda öğretmenin tükenmişliği: Teknoloji kullanımı ve tükenmişliği önlemeye yönelik alınabilecek önlemler.Akdeniz Eğitim Araştırmaları Dergisi, 9, 13-26.

Bektaş, F.,\& Nalçac1, A. (2012). The relationship between personal values and attitude towards teaching profession. Educational Sciences: Theory \& Practice, 12(2), 1244-1248.

Brophy, J.,\& Good, T. (1986). Teacher behavior and student achievement. In M. Wittrock (Ed.), Handbook of research on teaching (3rd ed., 328-375). New York: Macmillan.

Can, N. (2004). Öğretmenlerin geliştirilmesi ve etkili öğretmen davranışları. Sosyal Bilimler Enstitüsü Dergisi, 16, 103-119.

Çakıroğlu, A., (2013). Değerler eğitiminde korku kültürünün etkisi. (Yayımlanmamış yüksek lisans tezi). Abant İzzet Baysal Üniversitesi, Bolu.

Çalışkan, M., Işık, A. N.,\& Saygın, Y. (2013). Öğretmen adaylarının ideal öğretmen algıları. Ilköğretim Online, 12(2), 575-584.

Çelikten, M.,\& Can, N. (2003). Yönetici, öğretmen ve veli gözüyle ideal öğretmen. Selçuk Üniversitesi Ĕ̈itim Fakültesi Dergisi, 15, 253-267.

Çengelci, T., Hancı, B.,\& Karaduman, H. (2013). Okul ortamında değerler eğitimi konusunda öğretmen ve öğrenci görüşleri. Değerler Ĕ̆itimi Dergisi, 11(25), 33 56.

Çevik, D. B. (2011). Müzik öğretmeni adaylarının iletişim becerileri. Gazi Ĕ̆itim Fakültesi Dergisi, 31(1),1-13.

Çubukçu, Z., \& Girmen, P. (2008). Öğretmenlerin sınıf yönetimi becerilerine ilişkin görüşleri. Bilig, 44, 123-142.

Doğanay, A. (2010). Değerler eğitimi, C. Öztürk (Ed.) içinde, Sosyal Bilgiler öğretimi. Ankara: Pegem Akademi.

Doğanay, A.,\& Sarı, M. (2004). İlköğretim ikinci kademe öğrencilerine temel demokratik değerlerin kazandırılma düzeyi ve bu değerlerin kazandırılması sürecinde açık ve örtük programın etkilerinin karşılaştırılması. Eğitim Yönetimi, 10(39), 356-383. 
Erdemir, N., Bakırc1, H.,\& Eyduran, E. (2009). Öğretmen adaylarının eğitimde teknolojiyi kullanabilme özgüvenlerinin tespiti. Türk Fen Eğitimi Dergisi, 6(3), 99-108.

Gençtürk, E., Akbaş, Y., \& Kaymakçı, S. (2012). Sosyal Bilgiler öğretmen adaylarının bakış açısıyla ideal öğretmenin özellikleri. Kuram ve Uygulamada Ĕgitim Bilimleri, 12(2), 1559-1572.

Gül, R. (2013). Bir dĕger ĕgitimi olarak ilköğretim döneminde doğruluk eğitimi.(Yayımlanmamış yüksek lisans tezi). Hitit Üniversitesi, Çorum.

Halstead J. M., \&Taylor, M. J. (2000). Learning and teaching about values: A review of recent research. Cambridge Journal of Education, 30, 169-202.

Keith-Spiegel, P., Wittig, A. F., Perkins, D. V., Balogh, D. W., \& Whitley, B. E. (1993). Fairness in the classroom. APS Observer, 13(6), 34-35.

Keskin, Y. (2008). Türkiye'de Sosyal Bilgiler öğretim programlarında dĕ̌gerler ĕgitimi: tarihsel gelişim 1998 ve 2004 programlarının etkililiğinin araştırılması (Yayımlanmamış doktora tezi). Marmara Üniversitesi, İstanbul.

Merriam, S. B. (2009). Qualitative research: A guide to design and implementation (2nd ed.). San Francisco: Jossey-Bass.

Okoro, O. C. (2011). The ideal teacher and the motivated student in a changing environment. Journal of Educational and Social Research, 1(3), 107-112.

Okumuş, E. (2010). Toplum ve ahlak eğitimi. Eğitime Baklş Dergisi, 6(18), 28-32.

Önen, A. S. (2012). Öğretmen adaylarının kişilik özellikleri ve duygusal zeka düzeylerinin stresle başa çıkmalarına etkileri. Hacettepe Üniversitesi Ĕgitim Fakültesi Dergisi, 42, 310-322.

Özdaş, F. (2013). Ortaokullarda değerler ĕgitimi ve istenmeyen öğrenci davranışlarına ilişkin öğretmen görüşlerinin değerlendirilmesi (Yayımlanmamış doktora tezi). Firat Üniversitesi, Elazı̆̆.

Özensel, E. (2003). Sosyolojik bir olgu olarak değerler. Değerler Ĕ̆itimi Dergisi, 1(3), 217-240.

Öztürk, B., Koç, G., \& Şahin, F. T. (2002). Öğretmen beklentileri üzerine bir araştırma. TSA, 6(3), 123-144.

Pehlivan, B. K. (2005). Öğretmen adaylarının iletişim becerisi algıları üzerine bir çalışma. Illkögretim Online, 4(2), 17-23.

Sarı, M. (2007). Demokratik değgerlerin kazanımı sürecinde örtük program: Düşük ve yüksek "okul yaşam kalitesi”"ne sahip iki ilköğretim okulunda nitel bir çalışma (Yayımlanmamış doktora tezi). Çukurova Üniversitesi, Adana.

Sünbül, M. (1996). Öğretmen niteliğ̀i ve öğretimdeki rolleri. Eğitim Yönelimi, 1, 597607.

Şahin, A. (2011).Öğretmen algılarına göre etkili öğretmen davranışları. Ahi Evran Üniversitesi Ĕ̈itim Fakültesi Dergisi, 12(1), 239-259.

Türk Dil Kurumu (2014). www.tdk.gov.tr adresinden 02.07.2014 tarihinde alınmıştır. 
Yalar, T. (2010). İlköğretim Sosyal Bilgiler programında değerler eğitiminin mevcut durumunun belirlenmesi ve ögretmenlere yönelik bir program modülü geliştirme (Yayımlanmamış doktora tezi). Mersin Üniversitesi, Mersin.

Yaylacı, A. F. (2013). Öğretmenlerin kendilerini geliştirmelerine ilişkin yaklaşım sorunu. Uşak Üniversitesi Sosyal Bilimler Dergisi, Özel Sayl, 25-40.

Yıldırım, A., Ünal, A., \& Çelik, M. (2011). Öğretmen kavramına ilişkin öğretmen, yönetici ve müfettiş algılarının analizi. Uluslararası İnsan Bilimleri Dergisi,8(2), 92-109.

Yıldırım, A., \&Şimşek, H. (2006). Sosyal bilimlerde nitel araştırma yöntemleri (5. bask1). Ankara: Seçkin Yayıncılık.

Yıldırım, K (2009). Values education experiences of Turkish class teachers: A phenomeonological approach. Eurasian Journal of Educational Research, 35, 165-184.

Yılmaz, B. (2005). Öğretmenlik nasıl bir meslektir? Öğretmenin dünyası. Ankara: Odunpazarı Belediyesi Yayınları.

Yılmaz, E. (2009). Öğretmenlerin değer tercihlerinin bazı değişkenler açısından incelenmesi. De ğerler Ĕ̈itimi Dergisi, 17(7), 109-128.

Yılmaz, M. (2012). Değişen öğrenci, değișen öğretmen. Dem Dergi, 2(6), 120-123.

Yiğittir, S., \& Öcal, A. (2011) Lise Tarih öğretmenlerinin değerler ve değerler eğitimi konusundaki görüşleri. KMÜ Sosyal ve Ekonomik Araştırmalar Dergisi, 13(20), 117-124.

Yüksel, İ.,\& Adıgüzel, A. (2012). Öğretmenlerin okul temelli mesleki gelişim modeline ilişkin görüşlerinin çeşitli değişkenlere göre değerlendirilmesi. Mukaddime, 6, 117-134. 